\title{
THE INFLUENCE OF A ROPES COURSE DEVELOPMENT PROGRAMME ON THE SELF-CONCEPT AND SELF-EFFICACY OF YOUNG CAREER OFFICERS
}

\author{
K STADLER \\ De Beers Consolidated Mines \\ M E KOTZE \\ Faculty of Military Science \\ Stellenbosch University
}

\begin{abstract}
The aim of this study was to determine whether adventure training could be utilised to enhance the self-concepts and self-efficacy of young career officers in the South African National Defence Force. A quasi-experimental design with a pre-test, post-test and post-post-test was used. Two measuring instruments were administered, namely the Self-description Questionnaire III and the General Self-efficacy Scale. No statistically significant improvement was measured in the various dimensions of the self-concepts and self-efficacy of members of the experimental group, but some encouraging indications of change in the experimental group were observed after the intervention. The implications of the findings are discussed further.
\end{abstract}

\section{OPSOMMING}

Die doel van hierdie studie was om te bepaal of avontuurgerigte opleiding gebruik kan word om die selfkonsep en selfdoeltreffendheid van jong beroepsoffisiere in die Suid-Afrikaanse Nasionale Weermag te bevorder. 'n Kwasieksperimentele ontwerp met 'n voortoets, na-toets en na-na-toets is gebruik. Twee meetinstrumente is aangewend, naamlik die "Self-description Questionnaire III" en die "General Self-efficacy Scale". Hoewel geen statisties beduidende verbetering in die verskillende dimensies van die selfkonsep en selfdoeltreffendheid van lede van die eksperimentele groep gemeet is nie, is bemoedigende aanduidings van verandering in die eksperimentele groep na die intervensie waargeneem. Die implikasies van die bevindinge word verder bespreek.

Since 1994 the approach to training of career officers in the South African National Defence Force (SANDF) has changed dramatically. To a large extent this stemmed from extensive changes in the legislation, which govern the education and training policies on national level. One of the changes that these new acts and policies brought about was the implementation of a new Education, Training and Development (ETD) approach, specifically outcomes-based training. This introduced an exciting new era in the philosophy of - and approach to training in the SANDF. Where the emphasis in the past used to be on the instructor and the quality of instruction, the focus has now shifted to the competency of the learner (Department of Defence, 2003). In line with the new approach the SANDF has introduced a variety of methods and techniques to develop the leadership styles of young officers. These methods include the use of adventure-based programmes, such as low and high ropes courses. The SANDF invests a great deal of resources in such training courses and interventions, in order to develop the young career officers' physical fitness, leadership skills and selfconcepts. This study is especially interested in the effect of adventure-based programmes on the self-concepts of young career officers. Trainers currently measure the effectiveness of these programmes through interviews and feedback questionnaires, but no official empirical research in this field has been documented

Adventure training originated from the Outward Bound concept that was initiated by Kurt Hahn in the early nineteen forties in Aberdovey, Wales (Flurie, 2005). The application of adventure as a medium to develop people proved to be very successful and was further adapted during the next decade by the armed forces in Britain to enhance qualities, such as fitness, self-confidence, initiative and endurance (Priest \& Gas, 1997).

Traditionally adventure-based training created strenuous physical conditions in order to determine how learners could cope with the pressures of physical exhaustion, or even at times as an instrument to punish them. In contrast with this approach, the tendency today is to utilise adventure for the development of learners (Ernst, 2001; Kriek, 2002; Flurie, 2005). In this respect the use of adventure-based training courses as an intervention medium for the improvement of the self-concept has grown rapidly and the self-concept has become one of the most researched outcome factors in adventure education (Cason \& Gillis, 1994; Ewert, 1986; Hattie, Marsh, Neill \& Richards, 1997). However, research results of the effect of such training on participants' self-concepts and self-efficacy are very contradictory. Some studies revealed no significant differences in pre- and post-measures (e.g. Kaly \& Heesacker, 2003; Spinaze, 1986; Steyn, 2001; Wagner, Baldwin \& Roland, 1991) while others reported significant improvements (e.g. Clifford \& Clifford, 1967; Davis-Berman, 1989; Finkenberg, Shows \& DiNucci, 1994; Hazelworth \& Wilson, 1990; Neill, 1994; Nothnagel, 2003;). Graham and Weiner (1996) held that self-concept and selfefficacy were two self-beliefs of equal importance. Consequently, self-efficacy will also be incorporated into this study. The effect of adventure training on the self-concept and self-efficacy has so far not yet been investigated in the military context in South Africa.

The study had a dual aim: Firstly, to determine whether adventure training, and particularly ropes courses, could indeed be used to enhance the self-concept and self-efficacy of young career officers in the SANDF, and secondly, to determine the relationship between self-concept and self-efficacy. To begin with, self-concept and self-efficacy will be discussed. Thereafter adventure training will be reviewed, with specific reference to ropes courses. A summary of the more important national and international studies on the effect of adventure-based intervention programmes on the self-concept and self-efficacy of trainees will be provided. Next, the research methodology will be motivated, and finally, the research results will be reported and discussed in terms of the literature.

The self-concept

Individuals enter the military environment during late adolescence (Rabinowitz, 1982). During this stage the successful mastering of specific developmental tasks is a prerequisite for the dynamic functioning as a soldier. However, new entrees should not only be viewed in terms of 
the developmental challenges of late adolescence, but also within the context of the challenges and pressures inherent in the military system which may impact on their adjustment (Lieblich, 1989). For instance, the military is often described as the epitome of the male-dominated organisation, and military training primarily builds on and reinforces traditional male roles (DeFleur \& Warner, 1987). This is bound to exercise a decisive influence on the self-concepts of military trainees.

The importance of an individual's self-concept within the work environment is emphasised by the career development theory of Super (1990), which shows that both personal and worksatisfaction are not only determined by the successful integration of the different life roles, but also by the opportunity to implement the self-concept. As an individual's environment changes over time and with experience, so does his/her self-concept. Many authors believe that the self-concept is a multi-dimensional construct, encompassing cognitive, behavioural and affective components (Blascovich \& Tomaka, 1991; Flemming \& Courtney, 1984; Marsh, 1989; Marsh, Barnes \& Hocevar 1985; Marsh, Relich \& Smith, 1983; Marsh \& Shavelson, 1985; Shavelson, Hubner \& Stanton, 1976). Shavelson (in Marsh et al., 1985, p.1361) defined the selfconcept as "...Self-perceptions that are formed through one's experience with and interpretations of one's environment and influenced especially by evaluations by significant others, reinforcements, and one's attributions for one's own behaviour." Shavelson's self-concept model focuses on the emotional, social, physical and academic components of the self-concept. Although this multidimensionality of the selfconcept is not accepted universally, it is strongly supported by many researchers (Fleming \& Courtney, 1984).

According to Marsh (1989) the self-concept is constructed around 13 dimensions, namely mathematics, verbal ability, general school performance, problem solving, physical appearance, relationship with same sex, relationship with opposite sex, relationship with parents, spiritual values, honesty or reliability, emotional stability, total self and general self. Several intervention studies were designed to enhance specific aspects of this multi-dimensional self-concept. As mentioned earlier, self-concept and self-efficacy are viewed as two "self-beliefs" of equal importance. The discussion below will highlight selfefficacy as a self-belief.

\section{Self-efficacy}

Bandura (1986) used the term self-efficacy to describe the individual's belief that he/she is able to execute successfully the behaviours required by a specific situation. In this sense perceptions of personal efficacy may guide and direct the individual's behaviour (Mischel, 1986). Schwarzer and Jerusalem (1993) developed this concept further by distinguishing between task-specific self-efficacy (the perception of completing a task successfully) and general self-efficacy (the perception of competence over a wide spectrum of tasks and activities). The measuring instrument utilised in this study measures general self-efficacy. According to Bergh and Theron (1999), self-efficacy determines whether the individual will pursue a specific objective and how much effort will be put into attaining the stated objective. They argued that the higher the perception of self-efficacy, the more likely the individual will be motivated to persevere in attaining the objective, even if there are obstacles impeding him/her

\section{Adventure Training}

Gas, Goldman and Priest (1992) define adventure training as "carefully structured adventure experiences which are usually designed with specific needs in mind." When adventure is utilised specifically to ensure experience of all aspects of the personality - that is physically, emotionally, cognitively and spiritually - it is known as an adventure training programme. In an adventure training programme the experience of a new adventure serves as the vehicle by means of which participants improve their inter- and intra-personal skills (Mac Rea, Moore, Savage, Soehner \& Priest, 1993).

Adventure activities may be divided into three categories, namely group games, outdoor activities and ropes courses (Priest \& Gas, 1997). Group games focus on problem-solving and include tasks that vary in degree of difficulty in order to enhance teamwork, communication skills and thinking patterns. Outdoor activities focus on the experience itself and the inherent enjoyment or challenge. The present study focuses on ropes courses - the one category of adventure activities primarily aimed at risk taking. A ropes course consists of a series of obstacles higher than ground level, normally strung between high trees or poles, where individuals are subjected to certain challenges. Obstacles are crossed while the person's safety is ensured by a system of harnesses and safety ropes.

Miles (1978) speculates that the motivation to participate in adventure activities lies in the reward experienced by the participant, whereas Csikszentmihalyi's (1991) "flow theory" accentuates the participant's holistic sensation of pleasure, luck and competence. This intrinsic reward that the participant experiences is the individual's motivation to further participate in similar activities.

Apart from the individual's own experience of pleasure and competence, Goldenberg, Klenosky, O'Leary and Templin (2000) reported on research regarding other benefits of adventure training. They classified such benefits as the development of teamwork, trust, communication, risk taking, and self-esteem of the participants. Outdoor experiential training was also an effective moderator of students' feelings of anxiety-tension and depression (Kanters, Bristol \& Attarian, 2002). Similar to other adventure activities, ropes courses have a psycho-therapeutical application through which participants are exposed to and learn about interpersonal processes (Priest \& Gas, 1997). A further claim is that such programmes could enhance a participant's self-concept (Attarian, 1991). A good selfconcept will, in turn, have a positive effect on the individual's work performance (Greenhaus \& Badin, 1974; Super, 1990) and could thus also be beneficial to the organisation. The following section will reflect on research results referring to adventurebased training and the self-concepts and self-efficacy of participants in such programmes.

\section{Review of research}

A meta-analysis of the effect of outdoor adventure programming on adolescents was conducted by Cason and Gillis (1994). The focus of their study was to identify empirically-based studies concerning adventure programmes with an adolescent population, to compute and compare the overall outcomes of different programmes and to relate these outcomes to programme characteristics such as the length of a programme, the participating population and the study methodology. They found a significant positive correlation between the length of the programme and the effect size $(r=0,174, p=0,008)$, and a negative correlation for the age of adolescents participating in the study linked with effect size $(\mathrm{r}=-0,18, \mathrm{p}=0,01)$. Most effect sizes in the meta-analysis $(70,6 \%)$ emerged from studies without randomly assigned control groups. This implied that studies, which were questionable empirically, were more likely to have more positive findings. The authors speculated that researchers were perhaps attributing change in their research results when such change could be ascribed to chance. Nevertheless, results of this study demonstrated that adolescents who attended adventure-based programmes were $62 \%$ better off, based on the positive outcomes such as improved self-confidence, enhanced self-concepts and improved trust relationships than those who did not. 
Course components and programme design also seem to influence outcomes. McKenzie (2003), for instance, found that certain course components were more suitable to increase, inter alia, students' self-confidence, self-esteem, and self-concept. These components were closely linked to activities that provided the opportunity to achieve individual success, be responsible for oneself, learn new skills, have leadership responsibilities, and opportunities for challenge. Haras and Bunting (2005) further found that participant experiences of meaningful involvement in a ropes course programme were affected by programme design and delivery attributes.

Two instruments were mainly employed in the past to measure self-concept, namely the Tennessee Self-concept Scale (Hazelworth \& Wilson, 1990; Jones, 1978) and the Selfdescription Questionnaire (SDQ) 111 (Marsh, 1989; Marsh, Richards \& Barnes, 1986). An evaluation of the Outward Bound programme was the aim of many of these studies (Hattie et al, 1997; Jones, 1978; Marsh, 1989; Marsh, et al., 1986; Neill, 1994), all of which reported a positive effect on the total self-concept scores and/or some of the dimensions of the construct. Only one study reported on the effect of adventure-based interventions on self-efficacy (Propst \& Koesler, 1998). Results revealed a significant positive effect on self-efficacy in the long and short term.

Although the quoted research supported the notion that adventure-based training programmes had a positive effect on, inter alia, the self-concept and self-efficacy of participants, there were also researchers who doubted the real value of such interventions. Wagner et al., (1991) reported that 30\% of training directors indicated their doubt about outdoor training in three general areas: Firstly, whether the legal liabilities would outweigh the benefits or not, secondly, whether outdoor training was just another fad that would eventually fall from favour and, thirdly, whether adventure experiences were fun and games or real training. These are indeed very controversial questions. Regarding the legal liabilities it can only be commented that safety regulations enjoy a high priority amongst facilitators. The question remains thus whether such training renders real value or whether it could just be fun and games, or even a fad.

Relevant literature on similar research in the South African context is very restricted. Nothnagel (2003) found that people with a higher sense of coherence approached adventure training differently from those with a lower score on the Orientaion to Life Questionnaire. The empirical study by Steyn (2001) was, however, the most suitable to serve as benchmark for the current research. The participants (Public Order Police), the work environment (Public Sector Institution), as well as the intervention (Outdoor Experiential Learning Intervention) were comparable to those of the current study. To evaluate his intervention programme, Steyn (2001) used a four-group design with a pre-, post- and post-post test. The quantitative results postulated that outdoor experiential learning influenced participants' view of humanity positively, and could, therefore, be conducive to the development of interpersonal relations in the work place. Qualitative results showed that the intervention benefited changes in intrapersonal, interpersonal and group behaviour in the work place. The development of trust between participants, as well as increased levels of self-efficacy and optimism were reported, indicating a positive effect on the individual, the work group, and the organisation. For future research Steyn (2001) recommended that participants should be representative of the South African population; instruments that are sensitive towards the changes caused by outdoor programmes should be considered; and a four-group research design should be avoided, as such a design is too complex and its interdependency renders it difficult to accept the hypotheses without reservations.

\section{RESEARCH DESIGN}

Research approach

A quasi-experimental research design was used for the study. After authority for the project had been obtained from the Defence Force's Army Office and the units concerned, an adventure-based Ropes Course Development Programme was developed.

\section{Participants}

The research participants were selected from the first year group at the South African Military Academy. As all the first years could not be accommodated by the venue for the intervention, the experimental group was randomly selected by means of tabulated random numbers. The remaining first year students could not be utilised as a control group, as those students who were not selected for this study had to attend another military training programme. Only one group in the SA Army was comparable to the experimental group in terms of career development, experience and military rank, namely the young career officers from the Army Gymnasium, who were then randomly selected as a control group. Data screening revealed a high percentage of missing data for three of the respondents in the control group, which, according to the SDQIII Manual, could not be considered for analysis. These three cases were therefore omitted from further analysis. The sample valid cases were $\mathrm{N}=65$. The experimental and control groups were respectively $n=33$ and $n=32$.

The table below reflects the distribution of subjects in terms of possible covariates.

TABLE 1

DESCRIPTION OF THE SAMPLE IN TERMS OF AGE, GENDER AND ETHNIC GROUP

\begin{tabular}{|c|c|c|c|c|c|c|c|c|c|}
\hline & $\mathrm{N}$ & $\begin{array}{c}\text { Mean } \\
\text { Age }\end{array}$ & SD & Gender & $\mathrm{N}$ & $\begin{array}{l}\text { Percen- } \\
\text { tage }\end{array}$ & $\begin{array}{l}\text { Ethnic } \\
\text { group }\end{array}$ & $\mathrm{N}$ & $\begin{array}{l}\text { Percen- } \\
\text { tage }\end{array}$ \\
\hline \multicolumn{10}{|l|}{ Exp } \\
\hline \multirow{3}{*}{ Group } & 33 & 24,79 & 3,71 & Male & 27 & 81,8 & Black & 17 & 51,5 \\
\hline & & & & Female & 6 & 18,2 & Coloured & 7 & 21,2 \\
\hline & & & & & & & White & 9 & 27,3 \\
\hline \multicolumn{10}{|l|}{ Control } \\
\hline \multirow[t]{3}{*}{ Group } & 32 & 27,31 & 2,85 & Male & 21 & 65,6 & Black & 18 & 56,2 \\
\hline & & & & Female & 11 & 34,4 & Coloured & 6 & 18,8 \\
\hline & & & & & & & White & 8 & 25,0 \\
\hline
\end{tabular}

\section{Procedure}

A pre-test was administered one day prior to the intervention on both the experimental and the control group. The intervention was then conducted for the experimental group. The post-test followed on the last day of the intervention, and was administered on both groups. The experimental group then started their academic studies at the Military Academy, whilst the control group continued with their training at the Army Gymnasium. The post-post-test was administered on both groups after a period of eight weeks.

\section{The intervention}

The three-day Ropes Course Development Programme was designed and presented by facilitators from an adventure training provider. It addressed three main stages in personal development, namely: "where I come from, my current position and expectations, and finally, my relationships and interaction with others." The programme included warm-up activities, ice-breakers, low rope exercises (which were designed to ensure cooperation and the required physical effort to reach the stated goal) and high rope exercises (to identify and practice different support roles, and to assist individuals to stretch their personal limits). During the final stages of the 
intervention, the group was sensitised for discussions on topics that addressed issues such as social interaction and interpersonal relations.

\section{Measuring instruments}

Three measuring instruments were applied, namely a demographic inventory, the SDQIII (Marsh, 1989) and The General Self-efficacy (GSE) Scale (Schwartzer \& Jerusalem, 1993).

The demographic inventory was compiled to identify variables that might have an influence on the results of the SDQIII and the GSE Scale. Ethnic group, gender and age were incorporated in the analysis of data.

The SDQIII is one of a set of three self-description instruments designed to measure the self-concepts of preadolescents (SDQ), early adolescents (SDQII), as well as late adolescents and young adults (SDQIII). This set of SDQ instruments is based on the Shavelson self-concept model (Shavelson et al., 1976). The SDQIII measures four aspects of the academic self-concept (mathematical skills, verbal skills, academic ability and problem solving skills), eight aspects of the non-academic self-concept (religion, honesty, relations with opposite sex, emotional stability, relations with parents, physical appearance, relations with same sex, and physical ability), and a "General Self" based on Rosenberg's self image scale (Marsh, 1989). A total general self-concept score is also calculated to ensure comparability with other self-concept instruments that do not emphasise the multi-dimensionality of the self-concept. However, Marsh, (1989) emphasised that the focus should be on the specific scales, rather than the total score when interpreting SDQIII responses. The SDQIll shows satisfactory reliability coefficients (alpha coefficient for the 13 factors ranges from 0,76 to 0,95 ) (Marsh et al., 1983). This specific instrument was selected as it was designed for adolescents and young adults. It furthermore covers an academic as well as non-academic dimension of the selfconcept, which makes it suitable for application in a student sample.

The GSE Scale was created to assess a general sense of perceived self-efficacy with the aim to predict coping with daily challenges as well as adaptation after experiencing a variety of stressful life events (Schwarzer \& Jerusalem, 1993). The mean self-efficacy score measured by the GSE Scale is 29,46 with a standard deviation of $5,33(\mathrm{n}=17553)$ (Schwarzer \& Scholz, 2001). Criterion-related validity is documented in numerous correlation studies, while alpha coefficients ranged between 0,75 and 0,91 . The test-retest reliability ranges from $\mathrm{r}=0,55$ (2846 students over a period of one year), $r=0,69$ (surgery patients over a period of six months) to $\mathrm{r}=0,75$ (140 teachers over a period of one year) (Schwarzer \& Scholz, 2001).

\section{Statistical analysis}

The assumptions for parametric tests were checked for all variables used in the study and some variables violated both the assumption of normality and homogeneity of variance. In addition, the sample size placed a further restriction on the use of parametric statistics. Consequently non-parametric statistics were used.

The statistical analysis of data was pre-empted by explorative examinations in order to determine which of the classification factors should be considered as variables that could have had an influence on the outcome of the main analysis. For these analyses correlation coefficients (for age), t-tests (for gender) and Kruskal-Wallis tests (for ethnic group) were used. In the main analysis the Friedman test was used to determine whether there were any statistically significant changes in the distribution of the experimental and control groups from time period to time period. In those instances where significant differences were identified Wilcoxon tests were used for post hoc comparisons as to assess where the differences were located (Field, 2000; Pett, 1997). The critical alpha value was first adjusted using Bonferroni's inequality measure to take into account the potential for an increased Type I error. The original $\alpha=0,05$ and $\mathrm{k}=3$; therefore, the null hypotheses were rejected if the significance level was less than 0,017 (Field, 2000; Pett, 1997). To determine whether there was a significant difference between the scores of the experimental and control groups, the Mann-Whitney U test was used (Pett, 1997).

\section{RESULTS}

Evidence of a number of significant relationships was found between the age (Spearman correlation coefficients), and gender (Point-biserial correlation) of the experimental and control groups and the subscales of the SDQIII as well as the GSE Scale. Ethnic group (Kruskal-Wallis test) only showed a relationship with the dependent variables for the control group. As the effect of relationships cannot be compensated for in non-parametric statistics, these effects will be borne in mind when interpreting the results. Significant test statistics will be supplied, where applicable, in the discussion.

The results of the Friedman, Wilcoxen and Mann-Whitney tests are reported in Table 2 .

The SDQIII total score and the GSE correlated as depicted in Table 3 below.

\section{DISCUSSION}

The discussion starts with the changes in the SDQIII measurements across the three time periods. The moderating effect of age, gender, and race will be highlighted where applicable, as well as significant differences between groups. This is followed by an indication of the possible differences in the general self-efficacy measurement across the three time periods, and thirdly, the relationship between the self-concept and self-efficacy measurements will be investigated.

\section{Changes in the SDQIII measurements}

The experimental group exhibited a significant increase in their total general self-concept scores on the SDQ1ll before and after the intervention. One's first thought is to attribute this increase to the effect of the intervention. However, in contrast to the findings of Neill (1994), there was no significant difference in the scores between the experimental and control groups before and after the intervention. Consequently the experimental group's increase cannot solely be attributed to the intervention. Other factors could also have contributed to the change. Firstly, age could have acted as an intervening variable. On average, the experimental group was two years younger than the control group. Super's (1990) career development theory states that stability in the self-concept increases from late adolescence to early adulthood. The selfconcepts of the control group might thus have been more firmly established than those of the experimental group and, therefore, the change in the last group's scores. Secondly, the status dynamic conceptualisation of the self-concept (Bergner \& Holmes, 2002), states that the self-concept resists change, regardless of apparently disconfirming facts (Baumeister, 1995; Ossorio, 1978; Swann, 1992 in Bergner \& Holmes, 2002). The choice to pursue a military career can be related to a specific self-concept for both the experimental and control groups. The young career officers in the experimental group most probably resisted evidence of the intervention to be disconfirming of their perceived status and, therefore, did not change enough so 
TABLE 2

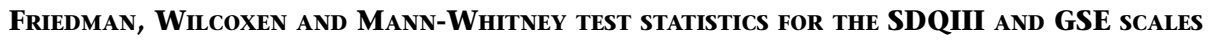

\begin{tabular}{|c|c|c|c|c|c|c|c|c|c|}
\hline \multicolumn{10}{|c|}{ SDQ III SUB-SCALES } \\
\hline \multirow[b]{2}{*}{$\begin{array}{l}\text { Self-concept } \\
\text { regarding }\end{array}$} & \multicolumn{3}{|c|}{ Experimental group } & \multicolumn{3}{|c|}{ Control group } & \multirow{2}{*}{\multicolumn{3}{|c|}{$\frac{\text { Experimental vs control group }}{\text { Mann-Whitney U }}$}} \\
\hline & Friedman $\mathrm{X}^{2}$ & Wilcoxen & $\mathrm{p}<0,017$ & Friedman $X^{2}$ & Wilcoxen & $\mathrm{p}<0,017$ & & & \\
\hline $\begin{array}{l}\text { Mathematical Skills } \\
\text { Religion }\end{array}$ & $\begin{array}{c}0,810 \\
12,2^{*}\end{array}$ & $\begin{array}{l}z=-3,270 \\
z=-2,536\end{array}$ & $\begin{array}{l}\text { pre }<\text { post } \\
\text { pre }<\text { p/p }\end{array}$ & $\begin{array}{l}16,197^{*} \\
4,08\end{array}$ & $z=-3,843$ & post $<$ p/p & $\begin{array}{l}-0,145 \\
-1,399\end{array}$ & $\begin{array}{l}-0,072 \\
-0,703\end{array}$ & $\begin{array}{r}-0,834 \\
-0,217\end{array}$ \\
\hline General self & 5,248 & & & 0,839 & & & $-0,401$ & $-0,092$ & $-0,263$ \\
\hline Honesty & 3,138 & & & 0,839 & & & $-0,336$ & $-0,079$ & $-0,099$ \\
\hline Relation with opp sex & 3,271 & & & 1,529 & & & $-1,741$ & $-1,254$ & $-0,867$ \\
\hline Verbal skills & $14,516^{* *}$ & $z=-3,673$ & post $>\mathrm{p} / \mathrm{p}$ & 0,797 & & & $-0,933$ & $-1,151$ & $\begin{array}{l}-2,320^{*} \\
\text { contr }>\exp \end{array}$ \\
\hline Emotional stability & 7,291 * & none sign & & 3,5 & & & $-0,716$ & $-0,099$ & $-0,184$ \\
\hline Relation with parents & $7,468^{*}$ & $z=-2,459$ & pre $<$ post & 1,350 & & & $-1,5,5$ & $-0,624$ & $-0,677$ \\
\hline Academic ability & 10,838 ** & $\begin{array}{l}z=-2,988 \\
z=-2,593\end{array}$ & $\begin{array}{l}\text { post }>\mathrm{p} / \mathrm{p} \\
\text { pre }>\mathrm{p} / \mathrm{p}\end{array}$ & 1,423 & & & $-0,625$ & $-1,257$ & $\begin{array}{c}-2,405^{*} \\
\text { contr }>\exp \end{array}$ \\
\hline Problem-solving ability & 1,565 & & & 1,067 & & & $-1,328$ & $-0,191$ & $-1,472$ \\
\hline Physical appearance & 3,438 & & & 4,186 & & & $-0,913$ & $-0,414$ & $-0,631$ \\
\hline Relation with same sex & 3,600 & & & 2,475 & & & $-0,355$ & $-0,926$ & $\begin{array}{c}-1,997^{*} \\
\exp >\text { contr * }\end{array}$ \\
\hline Physical ability & 0,455 & & & 3,185 & & & $-1,077$ & $-0,855$ & $-0,335$ \\
\hline
\end{tabular}

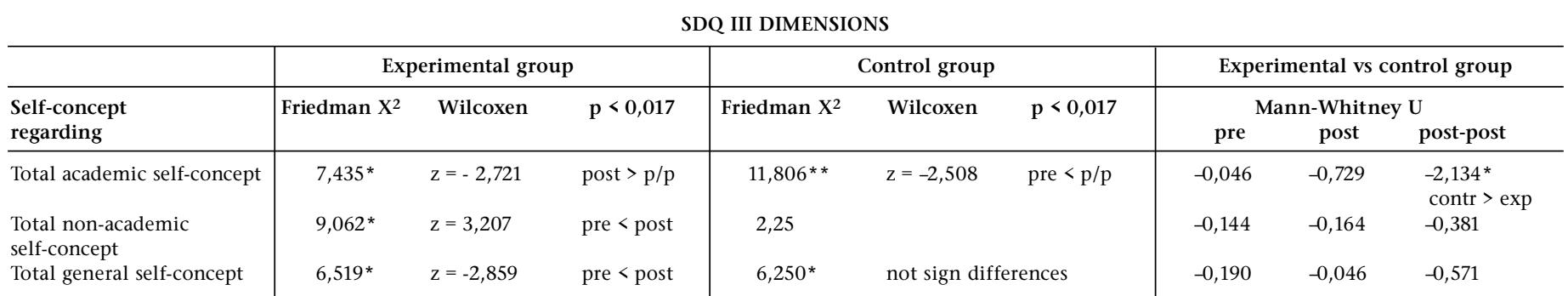

\begin{tabular}{|c|c|c|c|c|c|c|c|c|c|}
\hline Total general self-concept & $6,519^{*}$ & $z=-2,859$ & pre $<$ post & $6,250^{*}$ & not sign di & ences & $-0,190$ & $-0,046$ & $-0,571$ \\
\hline \multicolumn{10}{|c|}{ GENERAL SELF-EFFICACY SCALE } \\
\hline & \multicolumn{3}{|c|}{ Experimental group } & \multicolumn{3}{|c|}{ Control group } & \multicolumn{3}{|c|}{ Experimental vs control group } \\
\hline \multirow[t]{2}{*}{$\begin{array}{l}\text { Self-concept } \\
\text { regarding }\end{array}$} & Friedman $\mathrm{X}^{2}$ & Wilcoxen & $\mathrm{p}<0,017$ & Friedman $\mathrm{X}^{2}$ & Wilcoxen & $\mathrm{p}<0,017$ & \multicolumn{3}{|c|}{ Mann-Whitney U } \\
\hline & 3,379 & & & $10,362 * *$ & $z=-2,711$ & pre $<\mathrm{p} / \mathrm{p}$ & $-0,059$ & $-0,464$ & $-0,660$ \\
\hline
\end{tabular}

${ }^{*} \mathrm{p}, .05 * * \mathrm{p}<.001$

as to distinguish themselves statistically from the control group. As could be expected (as there was no intervention) officers in the control group did not change significantly between any of the measurements.

\section{TABLE 3}

RELATIONSHIP BETWEEN THE SDQIII AND GSE

\begin{tabular}{lll}
\hline Experimental Group & Correlation coefficient & Significance level \\
\hline Pre-test & $\mathrm{r}=.380$ & $\mathrm{p}<.05$ \\
Post-test & $\mathrm{r}=.484$ & $\mathrm{p}<.01$ \\
Post-post-test & $\mathrm{r}=.571$ & $\mathrm{p}<.01$ \\
& & Significance level \\
Control Group & Correlation coefficient & $\mathrm{p}<.05$ \\
Pre-test & $\mathrm{r}=.447$ & $\mathrm{p}>.05$ \\
Post-test & $\mathrm{r}=.326$ & $\mathrm{p}<.01$ \\
Post-post-test & $\mathrm{r}=.476$ & \\
\hline
\end{tabular}

The total academic self-concept score of the experimental group decreased between the post-test and post-post-test. This is in contrast to Neill (1994), who found a positive change in his experimental group's self-concept regarding their academic ability after an adventure-based intervention. Results further indicated that the sub-tests contributing to the decrease in the present study were the verbal skills and academic ability selfconcept scores. The significant decrease in the experimental group's score may be attributed to the post-post-test being conducted directly after completion of the students' first academic test series at the Military Academy. In this first official academic evaluation the students generally obtain poor marks.
This experience most probably came as a shock for the students' existing self-concepts in this area, and may, therefore, have contributed to the decline in scores. The influence of this negative experience is further reflected through the MannWhitney test showing significantly lower academic self-concept scores for the Military Academy students as compared to the Army Gymnasium members on the post-post measurement.

That the intervention as such did not have a significant influence on the academic self-concepts of the experimental group did not come as a surprise. Total academic self-concept and its sub-scales were not logically attached to the intervention, and should consequently not be affected by the intervention (Marsh et al., 1986). This finding can thus be interpreted as supporting these authors' hypotheses and is also an indication of the validity of the results of the present study. The total academic self-concept score of the control group increased between the pre-test and post-post-test. This correlates with an increase in their mathematical skills self-concept scores. A possible explanation for the significant increase in the control group's mathematical skills self-concept score may be the successful mastering of new competencies and skills as part of the training programme for young career officers at the Army Gymnasium. The mathematical challenges in this course were not as severe as for the experimental group at the Military Academy. Race correlated on this sub-scale on all three test occasions for the control group, but not for the experimental group. $(\mathrm{K}-\mathrm{W}=8,666, \mathrm{p}=0,013$; $\mathrm{K}-\mathrm{W}=$ $8,025, \mathrm{p}=0,018 ; \mathrm{K}-\mathrm{W}=9,216, \mathrm{p}=0,01$ )

The Friedman test indicated that there were statistically significant changes within the experimental group between the 
three time periods on their total non-academic self-concept scores. According to Marsh (1989) it seems logical that the Ropes Course Development Programme should bring about more change in the non-academic than academic areas of the selfconcept - areas that were more relevant to the aim of the programme. However, no significant differences were found between the experimental and control groups. Consequently it remains risky to attribute the experimental group's improved non-academic self-concepts solely to the intervention.

Within the experimental group changes were observed only between the pre-test and post-test and were not maintained over time. The change in self-concept scores over this short time period could be the effect of post-group euphoria that participants typically feel at the end of an extensive group experience. Post-group euphoria-bias is considered to be a particularly viable threat to the validity of conclusions based on self-report data and neither a time-series design, nor randomly assigned no-treatment control groups provide protection against such a risk (Marsh, 1989).

Besides the possible effect of post-intervention euphoria, the length of the intervention could also have influenced the outcome, as the literature indicated a significant positive correlation between the length of the programme and its effect on the self-concept (Cason \& Gillis, 1994; Marsh, 1989). In the light of this explanation, it appears that the present three-day adventure programme cannot be considered as effective in terms of its duration. Furthermore, a meta-analysis by Cason and Gillis (1994), found that the age of adolescents participating in adventure programming was negatively linked with effect size ( $\mathrm{r}$ $=-0,18, \mathrm{p}=0,01$ ), implying that younger participants were benefiting more than older participants from adventure-based programmes. The average age of the adolescents included in the meta-analysis was 15,8 years with a standard deviation of 0,92 . This may further explain why the impact of the Ropes Course Development Programme in the present study was not as powerful on the experimental group with an average age of 25 years, and could, therefore, not be maintained.

Sub-tests contributing to the change in the non-academic selfconcept scores of the experimental group are the religious/spiritual values and sub-test regarding relations with parents. On both tests the experimental group revealed significant increased median scores. Similar changes did not occur within the control group. This significant increase might be attributed partially to the Ropes Course Development Programme during which "relationships" were addressed in the discussion sessions. The fact that changes on this non-academic dimension, which was specifically addressed during the intervention, were reflected in the increased scores of the experimental group, supported the validity of the results of this study. The question could rightly be asked whether is was the intervention or the discussions that made the difference. The two were indeed intertwined. The researchers are of the opinion that it must have been the intervention as the discussions reflected on the adventure experience. It should, however, be noted that the impact of the intervention was apparently not sufficiently strong to engender a significant difference between the experimental and control group scores.

Although no differences were found between time periods in the control group, their age, gender and ethnic group correlated on various occasions with the sub-scales on religion and relations with parents. (Age: Pre-test: Religion $r=0,478, p=0,006$; Relations with parents $\mathrm{r}=0,631, \mathrm{p}=0,000$; Post-post test: Relations with parents $r=0,170, p=0,016$; Gender: Pre-test: Relations with parents: $r=0,423, p=0,016$; Post-test: $r=0,474, p$ $=0,006$; Post-post test: $r=0,449, p=0,01$; Ethnic group: Pre-test: Religion K-W $=9,253, p=0,01$ ) Previous research on the SDQIII scales indicated that there were age and gender influences on the SDQIII scales (Marsh, 1989). According to the SDQIII Manual this should not cause concern since the size of the age effects is said to be typically small and mostly reaching significance only when the sample size is very large. Furthermore it is indicated that age and sex differences decline with age and account for less than $1 \%$ of the variance (Marsh, 1989). The present results are thus contrary to this expectation, as the experimental group was on average younger than the control group, and yet no significant correlation was found for these independent variables. Neither did ethnic group correlate with the sub-scales for this group. This could be an indication that the experimental group was not only a more homogeneous group in terms of age, but was also less divided along gender and racial lines.

\section{Differences in GSE measures}

The control group's feeling of self-efficacy increased during the eight weeks of this research. No changes were observed in the experimental group, and no significant differences were found between the median GSE scores of the experimental and control groups during any of the three measurements. Again age and gender correlated with the GSE scores only for the control group.

Previous research concerning the effect of outdoor programmes on the self-efficacy of participants delivered contradictory results. On the one hand a study by Propst and Koesler (1989) showed a positive effect on self-efficacy in both the short and long term. On the other hand the South African study by Steyn (2001) found no significant difference between the GSE scores of the experimental and control groups (members from the Public Order Police) over three time intervals. The results of the present study thus support the findings of Steyn.

Steyn's (2001) study adds to the understanding of the reasons why the intervention did not bring about any significant changes in the GSE scores of the experimental groups. He explains that self-efficacy could be viewed as a social cognitive concept, and should, therefore, be explained within this context. According to the social cognitive theory, behaviour is considered to be the result of the complex interaction between individuals, environmental and situational variables (Bandura, 1986). The organisational structure of both the police and the military has a long history of bureaucracy and strict disciplinary codes, directing the behaviour of employees. Based on this frame of reference, one could argue that participants in the present study, as well as those who were involved in Steyn's intervention, were not in a position to regulate their behaviour within the work environment. Therefore, the inability of individuals to change their behaviour in a specific situation because of its structure, as well as environmental influences, could be the reason why, in both studies, the intervention did not have the desired effect.

Another possible explanation for the lack of change in the GSE measures of the experimental group may be attributed to the participants' self-beliefs. Because young career officers are not always proficient in making accurate self-appraisals in a military environment, they rely on the judgements and verbal persuasion of their superiors to create their own judgements of confidence and self-worth. It could well be that the young career officers in the experimental group found themselves in a period of transition during which they had to adapt to their new role as military students at the Military Academy. As they strove to exercise control over their surroundings, senior officers could either empower them with self-assurance, or diminish their fledging self-beliefs. It could be that the intervention was not effective in addressing these new demands on their self-beliefs to assist them in developing a feeling of greater self-efficacy. On the other hand the control group was on average two years older than the experimental group and their age correlated significantly with the GSE Scale. It may thus be assumed that they were more efficient in making self-appraisals in a military environment and that they did not rely as much on their superiors to create their own judgements of confidence and self-worth as the experimental 
group did. Moreover, this group remained in the original environment and consequently may have become more selfconfident. They did not have to adapt to a totally new environment as the experimental group had to.

Despite Bergh and Theron's (1999) argument that there is a difference in the perceptions of self-efficacy between men and women, only one measurement in the present study showed a gender difference, namely the control group's first measurement. Consequently it could be assumed that gender did not have a profound effect on the self-efficacy of the military participants in this study. There is also a strong possibility that this will be the case in the broader organisation, as the military has launched an active effort to employ and promote females (Department of Defence, 2003). The implication of this finding is that an occupation in the military may well be perceived as a neutral environment that provides opportunities in both the "traditional" male occupations and the "traditional" female ones.

\section{Relationship between SDQIII and GSE scores}

From the results reflected in Table 3 it is evident that there is a significant correlation between the SDQ1ll and the GSE scores. This is applicable to all test occasions except for the pre-test scores of the control group. These results pose strong support for Graham and Weiner (1996), who postulate that self-efficacy and self-concept are two self-beliefs of equal importance, where self-efficacy is a judgement of capability to perform a task or engage in an activity, and self-concept is a selfdescriptive judgement that includes evaluation of competence and the feelings of self-worth associated with the judgement in question.

\section{Conclusions}

The results of this research register significant positive shortterm changes of the experimental group's non-academic and general self-concept. However, no significant long-term improvement of the self-concepts of the participants in the adventure programme was observed. As no significant differences occurred between the experimental and control groups at any stage, it remains risky to attribute the changes that indeed occurred solely to the effect of the intervention. The reason for the lack of success of the intervention is most probably that it was not long and intensive enough to bring about a significant improvement in the self-concepts of participants. It could further be speculated that the intervention was offered in isolation and was not embedded in a more holistic curriculum. Consequently, the programme in this study should be considered as unsuccessful and not costeffective for the purpose of improving the relevant individuals' self-concept.

\section{Limitations}

In retrospect, this study was subjected to a number of limitations, which might appear to be shortcuts in the research process. However, all the limitations were beyond the researchers' control. One of the more serious limitations was that the control group was not in all aspects comparable with the experimental group. Although the two groups were at exactly the same stage in their careers, the control group was on average two years older than the experimental group. This most probably resulted from the fact that those who were selected to study at the Military Academy in that specific year were younger than the remainder of the cohort who stayed at the Army Gymnasium. This could hardly have been anticipated when the study was planned. Another limitation was the size of the experimental group. A larger sample was not possible because the Army allowed only a restricted budget for the intervention necessitating the use of a particular venue with limited capacity. A third limitation was that the interference of the academic test series for the experimental group created a rival hypothesis. The researchers were allocated a specific date by the Military
Academy to do the follow-up measurement, and this happened to be just after the students' test series. A final limitation concerns the use of non-parametric statistical procedures. As the distributions did not adhere to the pre-requisites of parametric statistics, less powerful non-parametric statistical methods had to be utilised.

\section{Recommendations}

In the first instance, the intervention should be longer and more intensive. The Ropes Course Development Programme should be structured in such a way that it forms a more integral part of the military curriculum of Military Academy students. Furthermore, future researchers should follow a true experimental design so as to exclude rival hypotheses, such as those that emerged in this study. Although Marsh et al. (1986) and Marsh (1989) administered the SDQIII to measure the effect of adventure-based training on the self-concept of Australian adolescents, similar research should be conducted where quantitative data is gathered by means of other instruments which are more sensitive to the impact of adventure-based programmes in a South African context.

Although no significant improvement was measured in the various dimensions of the self-concepts and self-efficacy of members of the experimental group after the intervention programme, some encouraging indications of change in the experimental group were observed after the intervention. The measurement of the effect of the programme was unfortunately complicated by various known variables (age, race and gender), but also unexpected variables intervening in the process (for example the specific date on which the postpost measurement could be done was determined by the Military Academy and could not be adapted). Nevertheless, continued research in this field remains highly relevant and should be encouraged. The following may serve as an inspiration for future researchers:

The wide variance in findings raises questions about the validity of quantitative research for this field, the reliability of instruments used for assessment of pre- and post-program changes, and the host of unknown variables that may be influencing both positive and negative effects of adventure programming. The more we can learn from each others' successes and mistakes through program evaluation and research, the more we can benefit our clients and ourselves in using adventure programming (Cason \& Gillis, 1994, p. 46).

\section{REFERENCES}

Attarian, A. (1991). Research on adventure (risk) recreation. Parks and Recreation, 26 (5), 19-23.

Bandura, A. (1986). Social foundations of thought and action: A social cognitive theory. Englewood Cliffs, NJ: Prentice Hall.

Baumeister, R. (1995). Self and identity: An introduction. In A. Tester (Ed.), Advanced social psychology (pp. 50-97). New York: McGraw-Hill.

Bergh, Z.C. \& Theron, A.L. (1999). Psychology in the work context. Cape Town: Oxford University Press South Africa.

Bergner, R.M. \& Holmes, J.R. (2002). Self-concepts and self-concept change: A status dynamic approach. World Wide Web (http://www.sdp.org/sdp/papers/selfconcept.html).

Blascovich, J., \& Tomaka, J. (1991). Measures of personality and social psychology attitudes. San Diego, CA: Academic Press.

Cason, D. and Gillis, H.L. (1994). A meta-analysis of outdoor adventure programming with adolescents. The Journal of Experiential Education, 17 (1), 40-47.

Clifford, E. \& Clifford, M. (1967). Self-concepts before and after survival training. British Journal of Social and Clinical Psychology, 6, 241-248.

Csikszentmihalyi, M. \& Csikszentmihalyi, I.S. (1991). Adventure and the flow experience. In J.C. Miles \& S. Priest (Eds). Adventure Education (pp. 149-155). State College, PA: Venture. 
Davis-Berman, J., \& Berman, D.S. (1989). The wilderness therapy program: An empirical study of its effects with adolescents in an outpatient setting. Journal of Contemporary Psychotherapy, 29, 271-281.

DeFleur, L.B. \& Warner, R.L. (1987). Air Force Academy graduates and non-graduates: Attitude and self-concepts. Armed Forces and Society, 13, (4), 517-533.

Department of Defence (RSA). (2003). Overarching policy framework for education, training and development in the Department of Defence. Pretoria: Department of Defence.

Ernst, E.A. (2001). Skills development. Handbook for SETAS, Employers and Employees in South Africa. Pretoria: Kitskopié (Pty) Ltd.

Ewert, A. (1986). Outdoor adventure activity programs: A new dimension. Journal of Physical Education, Recreation, and Dance, 57 (2), 56-57.

Field, A. (2000). Discovering statistics using SPSS for windows. London: SAGE Publications.

Finkenberg, M.E., Shows, D., \& DiNucci, J.M. (1994). Participation in adventure-based activities and self-concepts of college men and women. Perceptual and Motor Skills, 78, 1119-1122.

Flemming, S. \& Courtney, B.E. (1984). The dimensionality of self-esteem: Hierarchical facet model for revised measurement scales. Journal of Personality and Social Psychology, 46 (2), 404-421.

Flurie, M.E. (2005). Research Question Seminar: Talking Paper. Duquesne University. http://www.education.duq.edu/ currentStudents/pdf/R._Flurie_Tal.pdf

Gas, M., Goldman, K., \& Priest, S., (1992). Constructive effective corporate adventure training programs. The Journal of Experiential Education, 15 (1), 35-42.

Goldenberg, M.A., Klenosky, D.B., O'Leary, J.T. \& Templin, T.J. (2000). A means-end investigation of ropes course experiences. Journal of Leisure Research, 32 (2), 208-224.

Graham, S. \& Weiner, B. (1996). Theories and principles of motivation. In D.C. Berliner \& R. C. Calfee (Eds.) Handbook of educational psychology (pp. 63-84). New York: Simon \& Schuster Macmillan.

Greenhaus, J.H. \& Badin, I.J. (1974). Self-esteem, performance and satisfaction: Some tests of a theory. Journal of Applied Psychology, 59 (6), 722-726.

Haras, K. \& Bunting, C.J. (2005). The differences in meaningful involvement opportunities provided by ropes course programs. The Journal of Experiential Education, 27 (3), 207-209.

Hattie, J., Marsh, H.W., Neill, J.T., \& Richards, G.E. (1997). Adventure education and Outward Bound: Out-of-class experiences that have a lasting effect. Review of Educational Research, 67, 43-87.

Hazelworth, M.S. \& Wilson, B.E. (1990). The effects of an outdoor adventure camp experience on self-concept. Journal of Environmental Education, 21 (4), 33-37.

Jones, C.A. (1978). An evaluation of the effect of an Outward Bound-type program upon the self-concept and academic achievement of high school students. Unpublished doctoral dissertation, Boston University School of Education.

Kanters, M.A., Bristol, D.G. \& Attarian, A. (2002). The effects of outdoor experiential training on perceptions of college stress. The Journal of Experiential Education, 25 (2), 257-357.

Kriek, D. (2002). Adventure based team development effectively implemented. Management Today. July

Lieblich, A (1989). Transition to adulthood during military service: The Israeli Case. New York: State University: New York Press.

MacRae, S., Moore, C., Savage, G., Soehner, D., \& Priest, S. (1993). Changes in risk taking propensity resulting from a ropes course experience. The Journal of Adventure Education and Outdoor Leadership, 10 (2), 10-13.

Marsh, H.W. (1989). Self Description Questionnaire III Manual. University of Western Sydney: Macarthur.
Marsh, H.W., Barnes, J., \& Hocevar, D. (1985). Self-other agreement on multidimensional self-concept ratings: Factor analysis \& multitrait-multimethod analysis. Journal of Personality and Social Psychology, 49, 1360-1377.

Marsh, H.W., Relich, J.D. \& Smith, I.D. (1983). Self-concept The construct validity of interpretations based upon the SDQ. Journal of Personality and Social Psychology, 50 (1), 195-204

Marsh, H.W., Richards, G.E., \& Barnes, J. (1986). Multidimensional self-concepts: The effect of participation in an Outward Bound Program. Journal of Personality and Social Psychology, 45 (1), 173-181.

Marsh, H.W. \& Schavelson, R.J. (1985). Self-concept: Its multifaceted, hierarchical structure. Educational Psychologist, $20,107-125$

McKenzie, M. (2003). Beyond "The outward Bound Process:" Rethinking student learning. The Journal of Experiential Education, 26 (1), 8-23.

Miles, J.C. (1978). The value of high adventure activities. Journal of Physical Education, Recreation \& Dance, 49 (4), 27-28.

Mischel, W. (1986). Introduction to personality: A new look. (4th ed). New York: CBS College Publishing.

Neill, J.T. (1994). The effect of Outward Bound high school programs on adolescents' self-concept, mental health and coping strategies. World Wide Web (http://outwardbound.com. $\mathrm{au} /$ cor/ese-cont-scho-ab.htm).

Nothnagel, G.J. (2003). Die rol van sin vir koherensie in korporatiewe avontuuropleiding (The role of sense of coherence in corporative training). Unpublished MCom thesis Pretoria: Unisa. http://etd.unisa.ac.za/ETD-db/ETDdesc/describe?urn=etd-04292005-092433.

Ossorio, P. (1978). What actually happens. Columbia, SC: University of South Carolina Press.

Pett, M.A. (1997). Nonparametric statistics for health care research: Statistics for small samples and unusual distributions. California: SAGE Publications.

Priest. S. \& Gas, M.A. (1997). Effective leadership in adventure programming. United States of America: Braun-Brumfield.

Propst, D.B. \& Koesler, R.A. (1998). Bandura goes outdoors: Role of self-efficacy in the outdoor leadership process. Leasure Science, 20, 319-344.

Rabinowitz, S. (1982). Inauguration for adulthood: The military system as an effective integrator for adult adaptation, an Israel air force base perspective. Psychological Reports, 51. 1083-1086.

Schwarzer, R \& Jerusalem, M. (1993). General Self-efficacy. World Wide Web (http://www.fu-berlin.de/gesund/skalen/g_se.htm).

Schwarzer, R. \& Scholz, U. (2001). Cross-cultural assessment of coping resources: The general perceived self-efficacy scale. World Wide Web (http://www.fu-berlin.de/gesund/ publicat/world data.htm).

Shavelson, R.J., Hubner, J.J. \& Stanton, G.C. (1976). Validation of construct interpretations. Review of Education Research, 46, 407-441.

Spinaze, M. (1986). Changing Self-concepts: Outward Bound School Programme Impact. Brisbane: Brisbane College.

Steyn, R. (2001). Die ontwerp en evaluering van ' $n$ buitemuurse ervaringsleeringreep. Ongepubliseerde doktorale proefskrif, Potchefstroomse Universiteit vir Christelike Hoër Onderwys.

Super, D.E. (1990). A life-span, life-space approach to career development. In D. Brown, L. Brooks \& Associates, Career choice and development (2nd ed.)(pp. 197-261). San Francisco: Jossey-Bass.

Van der Horst, H \& McDonald, R. (2001). Outcomes-based Education: Theory and practice. Irene: Tee Vee Printers.

Wagner, R.J., Baldwin, T.T., \& Roland, C.C. (1991). Outdoor training: Revolution or fad? Training and Development Journal, 45 (3), 50-56. 